\title{
TOWARDS A STUDY OF MEMORY IN US TRANSATLANTIC RELATIONS: THE LATE COLD WAR
}

GYÖRGY TÓTH

\begin{abstract}
Probing the intersection of Memory Studies and International Relations, this article traces the uses of collective memory in late Cold War US Transatlantic relations. First it surveys the existing scholarly literature on the topic and critiques some selected methodological models. Next it discusses the politics of cultural memory in the United States itself. In its main body, the study focuses on the core of the use of memory in US Transatlantic relations: historical reasoning in the fields of 1) foreign policy decision-making, and 2) public or cultural diplomacy. The author argues that while the US government may not have had a centrally articulated and overarching policy for the use of collective memory in US diplomacy, such a policy can nevertheless be assembled out of its foreign policy training and the cultural diplomacy practices of the United States Information Agency, both of which continued throughout the 1990s, the first period of the post-Cold War era.
\end{abstract}

Keywords: United States, Cold War, memory, foreign policy, cultural diplomacy, transatlantic relations DOI: $10.14712 / 23363231.2015 .79$

In the spring of 2015 - the run-up to the seventieth anniversary of the end of World War Two - even an ordinary Internet search showed that recent public rhetoric has couched the ongoing crisis in the Ukraine in the terms of that past world conflict. It is not only sensationalist journalists, aged cold warriors or implacable Ukrainian nationalists who have been calling Russian president Vladimir Putin a modern day Hitler. Some of the highest dignitaries in the West who have made the same comparison include former US Secretary of State Hillary Clinton, Britain's Prince Charles, and the president of Lithuania - all public figures who know the power of words, and who are fully aware that their reference to Europe's darkest period will have a serious effect on the framing of the current 
crisis in Russian-Western relations. ${ }^{1}$ While they may be intended as a rhetorical line in the sand for Russia, such uses of the past likely exacerbate the conflict rather than de-escalating it. On the other side, Ukrainian Russian separatists and the Russian media and government have consistently blamed the conflict on Western "fascists" - which is their way of evoking their own narrative of the Great War in Defense of the Homeland against the Nazis and their collaborators 70 years ago - in order to mobilize their side in the current conflict.

Such heated rhetoric lays bare the potential of public memory to serve as a tool of propaganda or cultural diplomacy: to move, persuade, mobilize, and commit people to a cause or policy not only nationally, but also in international relations. Yet as important as they are, scholars, security analysts and government officials need to look not only for short-term preventative measures, but for a formulation of a coherent Transatlantic memory policy to support peaceful relations in Eastern Europe and the Baltics. In other words, government officials as well scholars of nationalism and memory should do more than include memory as one of the resources of international relations. They should identify what expressions of memory can be used in diplomacy, when and how - and develop models for a coherent memory policy.

This article looks for traces of such a memory policy in the use of collective memory in late Cold War US Transatlantic relations. ${ }^{3}$ First I will survey the existing scholarship on the topic, and critique some of its methodological models. Next I will

1 A few of the many media reports of such framing include "Hillary Clinton's Comparison of Vladimir Putin and Adolf Hitler Checks Out," ABC News Australia, March 31, 2014, http://www.abc.net.au /news/2014-03-25/hillary-clinton-putin-hitler-comparison-checks-out/5325608; Guy Faulconbridge and Alissa de Carbonnel, "Prince Charles Provokes Diplomatic Row by Comparing Putin to Hitler," Reuters, May 22, 2014, http://uk.reuters.com/article/2014/05/22/uk-britain-putin -prince-idUKKBN0E20P920140522; and "Lithuanian President Likens Putin to Stalin and Hitler," The Moscow Times, June 23, 2014, http://www.themoscowtimes.com/news/article/lithuanian -president-likens-putin-to-stalin-and-hitler/502332.html.

2 A few of the media reports of such framing include Neil MacFarquhar, "Putin Accuses U.S. of Backing 'Neo-Fascists' and 'Islamic Radicals"' New York Times, October 24, 2014, http://www.nytimes .com/2014/10/25/world/europe/vladimir-putin-lashes-out-at-us-for-backing-neo-fascists-and -islamic-radicals.html?_r=0; and Shaun Walker, "Donetsk's Pro-Russia Rebels Celebrate Expelling 'Fascist Ukrainian Junta,"' The Guardian, September 8, 2014, http://www.theguardian.com/world/2014 /sep/08/donetsk-pro-russia-rebels-ukrainian-junta.

3 This article discusses the author's preliminary findings in the multi-sited and multi-member research project "The Role of Collective Memory in Post-Cold War Transatlantic Relations," funded by the Grant Agency of the Czech Republic. The article also benefited from the author's post-doctoral research fellowship at the at the Centre for Collective Memory Research at the Institute of International Studies, Charles University, Prague, the Czech Republic, as well as from the author's research fellowship at the International Forum for U.S. Studies at the University of Illinois at Urbana-Champaign, Illinois, USA. 
discuss the politics of cultural memory in the United States itself, which I argue is dynamic, multi-player, yet still hierarchically structured. The main body of this study then focuses on the core of the use of memory in US Transatlantic relations: historical reasoning in the fields of 1) training for foreign policy decision-making; and 2) public or cultural diplomacy. First I will interpret as primary source a late Cold War university course textbook written to train future government officials in the application of historical analogies in decision making. I will conclude with an analysis of the United States Information Agency's overseas commemorative programming for the Bicentennial of the United States Constitution as a case study of the uses of collective memory in late Cold War US Transatlantic relations. My analyses demonstrate that while the US government may not have had a centrally articulated and overarching policy for the use of collective memory in US diplomacy, such a policy can nevertheless be assembled out of its foreign policy training and cultural diplomacy practices, both of which continued throughout the 1990s, the first period of the post-Cold War era.

\section{The Role of Memory in Transatlantic Relations}

Until early 2014, most scholars of US-European relations concluded that the Transatlantic bond has been weakened in the last decade, and some even seriously questioned its future. ${ }^{4}$ The focal point of most discussions on Transatlantic ties has tended to be the role of values on which the partnership has been built. According to Robert Kagan, fundamental differences in the approach towards new security threats, the use of force versus negotiation, the nature and merits of a globalized economy, and environmental issues all stand in the way of developing an effective partnership across the Atlantic in the future. ${ }^{5}$ On the other hand, Jeffrey J. Anderson, G. John Ikenberry and Thomas Risse suggested that the current disagreements may be neither fatal nor permanent, but minor and transient. ${ }^{6}$ They conclude that the strains in Transatlantic relations notwithstanding, the current crisis by no means signifies the "end of the West." Timothy Garton Ash was even more optimistic about the prospects of Transatlantic cooperation than Anderson et al. when he insisted that "there are not two separate sets of values, European

4 See Andrew Dorman and Joyce Kaufman, eds., The Future of Transatlantic Relations: Perception, Policy and Practice (Redwood City, CA: Stanford University Press, 2010).

5 See Robert Kagan, Of Paradise and Power: America and Europe in the New World Order (New York: Vintage Books, 2004).

6 See J. Jeffrey Anderson, G. John Ikenberry, and Thomas Risse, eds., The End of the West? Crisis and Change in the Atlantic Order (Ithaca, NY: Cornell University Press, 2008). 
and American, but several intersecting sets of values," that allow for successful and productive transatlantic cooperation. ${ }^{7}$

In sharp contrast to the previous decade, by the time of this writing (the spring of 2015), the crisis in the Ukraine has opened a new chapter in Transatlantic relations. Combined with efforts to reduce the region's dependence on Russian-supplied energy, the recent US and Western European economic sanctions against the Russian Federation, their political pressure, aid to the Ukrainian government, and the sending of US military materiel and troops to Eastern Europe and the Baltic states signal a tightening of the Transatlantic alliance in the face of Russian expansionism and civil strife in these parts of Europe. As demonstrated above, the crisis is often framed in terms of the memory of World War Two. This current use of memory in Transatlantic relations locks the parties into the current conflict by mobilizing their sides through an uncritical use historical analogies. While historians of the Second World War can map out the faults of such analogies, this article is concerned with an apparent lack of policy planning for the use of memory in Transatlantic relations. By adding an analysis of the politics of remembering, collective memory and representations of the past to the current discussions about the prospects of Transatlantic relations, this paper aims to contribute to filling a gap in scholarly literature.

The study of memory has a voluminous literature. As Duncan S. A. Bell has observed, since the 1970s memory has become a veritable "organizing principle of scholarly [and] artistic work" in sociology, anthropology, history and cultural studies. ${ }^{8}$ More recently, Patrick Finney has characterized the field of Memory Studies as a "vast interdisciplinary enterprise." 9 Theoretically developed first by Maurice Halbwachs, ${ }^{10}$ in recent years the concept of collective memory has been advanced in particular by Jan and Aleida Assmann. ${ }^{11}$ As Peter Novick argued, the key idea that emerged from this field was that the quest to reconstruct and codify an "objective history" was not as relevant to social reality as the perceptions of the

7 See Timothy Garton Ash, Free World: America, Europe, and the Surprising Future of the West (New York: Vintage Books, 2005), 168.

${ }^{8}$ Duncan S. A. Bell, ed., Memory, Trauma and World Politics (Basingstoke: Palgrave Macmillan, 2006), $1,7$.

9 Patrick Finney, "The Ubiquitous Presence of the Past? Collective Memory and International History," International History Review Vol. 36, No. 3 (2014): 445.

${ }^{10}$ Maurice Halbwachs, La Mémoire Collective (Paris: Presses Universitaires de France, 1950). English translation Collective Memory (New York: Harper \& Row Colophon Books, 1980).

11 Aleida Assmann, Cultural Memory and Western Civilization: Functions, Media, Archives (Cambridge: Cambridge University Press, 2011). 
past within collective memory. ${ }^{12}$ Depending on the scale of analysis, a smaller or larger variety of actors contribute to the construction and reproduction of collective memory.

The idea that collective memory is located primarily in the minds of a given community and thus can be used as an analytical category has been critiqued by a number of scholars. For one, Pauli Bauer has pointed out that such analytical use of the concept of collective memory privileges it as some kind of monolithic concept, erasing the diversity and dynamism of its formation, expressions, reproduction and transmission, and shifts in remembrance. ${ }^{13}$ Both Jeffrey K. Olick and Erica Resende and Dovile Budryte have argued that "memory should be treated as a 'sensitizing concept' (but not as an operational concept, a measurable phenomenon), drawing our attention to the importance of representations of the past (especially the traumatic past) in the construction of group identities." 14 As James V. Wertsch has cautioned, "We must remember that collective memory is a process and not a thing, a faculty rather than a place. Collective memory is something - or rather, many things - we do, not something or many things we have." ${ }^{15}$ Heeding such warnings, this article will not try to define the nature of collective memory - rather, it will focus on its manifestations, such as historical rhetoric in decision making and anniversaries and commemorations, in order to understand how it was used in late twentieth century US Transatlantic diplomacy. Collective memory is a potent political force, as it serves as an important frame of reference for proposed policies as well as for their public justification. There is an inherent tension between the desire for a more neutral view of history based primarily on the critical examination of evidence, and the utilitarian interpretation of selected events to serve political purposes. As pointed out by Langenbacher and Shain, understanding collective memory as a tool to mobilize people is highly relevant for international relations and international politics. ${ }^{16}$

This article joins a growing body of scholarship on the role of memory in an international context. Mostly during the last decade, scholars have been examining

12 Peter Novick, That Noble Dream. The "Objectivity Question" and the American Historical Profession (Cambridge: Cambridge University Press, 1988).

13 Dr. Pauli Bauer, personal communication, October 2014.

${ }^{14}$ Jeffrey K. Olick, The Politics of Regret. On Collective Memory and Historical Responsibility (New York: Routledge, 2007); and Erica Resende and Dovile Budryte, eds., Memory and Trauma in International Relations: Theories, Cases and Debates (New York: Routledge, 2014), 3.

15 James V. Wertsch, Voices of Collective Remembering (Cambridge: Cambridge University Press, 2002), 40.

16 Eric Langenbacher and Yossi Shain, eds., Power and the Past: Collective Memory and International Relations (Washington, D.C.: Georgetown University Press, 2010), 11. 
a variety of aspects of the topic, including the ways in which policy and decision makers utilize memory, ${ }^{17}$ the relationship between trauma, memory, and international politics, ${ }^{18}$ the multiplicity of actors who shape memory and thereby influence international relations, ${ }^{19}$ the uses of memory in the Global War on Terror, ${ }^{20}$ and the role of memory in the conflicts in post-Cold War Europe. ${ }^{21}$ The scholarly consensus is that "there is copious contemporary and historical evidence that collective memories can impact upon the course of international relations." 22 Yet as Patrick Finney has argued, scholars of international history need to take memory more seriously than they so far have. ${ }^{23}$ Among others, Finney's research agenda prescribes a renewed focus on the role of collective memory in international decision making 24 - which this paper will discuss in the context of late Cold War US foreign policy training. As I will show, however, this is a scholarly project fraught with

17 William Inboden, "Statecraft, Decision-Making, and the Varieties of Historical Experience: A Taxonomy," Journal of Strategic Studies Vol. 37, No. 2 (2014): 291-318; R. D. Schulzinger, "Memory and Understanding U.S. Foreign Relations," in Explaining the History of American Foreign Relations, ed. M. J. Hogan and T. G. Paterson (Cambridge: Cambridge University Press, 2004), 336-52; Roland Paris, "Kosovo and the Metaphor War," Political Science Quarterly, cxvii (2002): 423-50; and R. E. Neustadt and E. R. May, Thinking in Time: the Uses of History for Decision-Makers (New York: Simon \& Schuster, 1986).

18 Resende and Dudryte, eds., Memory and Trauma in International Relations; Olick, The Politics of Regret; and Bell, ed., Memory, Trauma and World Politics.

${ }^{19}$ Langenbacher and Shain, eds., Power and the Past.

20 Omer Bartov, "September 11 in the Rearview Mirror: Contemporary Policies and Perceptions of the Past"; Michael Kazin, "The Eventful Dates 12/12 and 9/11: Tales of Power and Tales of Experience in Contemporary History"; Jeffrey Herf, "The Use and Abuse of History in Berlin and Washington since 9/11: A Plea for a New Era of Candor"; and Thomas U. Berger, "Of Shrines and Hooligans: The Structure of the History Problem in East Asia after 9/11", in Power and the Past: Collective Memory and International Relations, ed. Eric Langenbacher and Yossi Shain (Washington, D.C.: Georgetown University Press, 2010), 147-60, 161-72, 173-88, and 189-202, respectively; D. B. MacDonald, Thinking History, Fighting Evil: Neoconservatives and the Perils of Analogy in American Politics (Lanham, MD: Lexington Books, 2009); D. Hoogland Noon, "Operation Enduring Analogy: World War II, the War on Terror, and the Uses of Historical Memory," Rhetoric and Public Affairs, vii (2004), 339-66; and Liam Kennedy, "Remembering September 11: Photography as Cultural Diplomacy," International Affairs 79 (2003): 315-26.

${ }^{21}$ Dan Stone, "Memory Wars in the New Europe," in The Oxford Handbook of Postwar European History, ed. Dan Stone (Oxford: Oxford University Press, 2012), 714-31; Maria Mälksoo, The Politics of Becoming European: a Study of Polish and Baltic Post-Cold War Security Imaginaries (New York: Routledge, 2010); Paris, "Kosovo and the Metaphor War," 423-50; D. B. MacDonald, Balkan Holocausts? Serbian and Croatian Victim-Centred Propaganda and the War in Yugoslavia (Manchester: Manchester University Press, 2002); and Jan-Werner Müller, Memory and Power in Post-War Europe: Studies in the Presence of the Past (Cambridge: Cambridge University Press, 2002).

22 Patrick Finney, "The Ubiquitous Presence of the Past? Collective Memory and International History," International History Review Vol. 36, No. 3 (2014): 457.

${ }^{23}$ Finney, "The Ubiquitous Presence," 449, 450, 464.

24 Finney, “The Ubiquitous Presence," 452. 
pitfalls; instead, it is more fruitful to analyze how collective memory is used in US foreign policy - and this is my real project here.

Much of the recent scholarly discussions concerned the precise nature and dynamics of collective memory, and thus the very conceptual framework that is used to study it. Several scholars have warned against the proliferation and indiscriminate use of the term memory, and have called for greater theoretical rigor as reflected in terminology. For one, Jay Winter has discarded the original term altogether and recommended the adoption of remembrance to denote a focus on the actors and the politics of remembering. ${ }^{25}$ The most nuanced of such interventions came from Duncan Bell, who advocated for a conceptual separation of collective memory and national mythology. For him,

Collective memory is understood as the process whereby groups of individuals share and to some extent harmonize (autobiographical) memories of past experiences, and it is therefore limited spatially and temporally. Myths, meanwhile, can escape the bounds of experience - they are simplified, highly selective and widely shared narrations of an imagined past, the stories that people and groups tell about their location (and meaning) in time. ${ }^{26}$

In Bell's formulation, only war veterans', trauma survivors' and historical witnesses' recollections could be called memory. Anything outside of these - among them cultural representations, rhetorical invocations, and non-witness social rituals of remembering - would have to be termed national mythology. While he acknowledges that "they interpenetrate and overlap at various points," Bell nevertheless insists that "it is essential to try and delineate them, even if this undertaking can never be achieved completely." 27

My formulation of memory takes issue with Bell's demarcation. Witnesses or participants of the original event are but one of the many groups in any society who shape collective memory; there is ample proof that while they exert some influence, they do not fully fix the meaning of historical events for the nation even in their own lifetime. Their experience and lessons derived from their (already multiple and conflicting) experiences of the original event are at best mediated through other social, cultural and political structures (including shifting political regimes, intergenerational communication, and the media and popular culture

25 Jay Winter, Remembering War: the Great War between Memory and History in the Twentieth Century (New Haven, CT: Yale University Press, 2006), 3.

26 Bell, Memory, Trauma and World Politics, 27, emphasis added.

27 Bell, 27. 
industry). What is more, with the passing of this witness generation, their experiences are increasingly folded into representations of national memory. (In national crises or under repressive regimes, their memories may even be silenced or at least driven underground.) Thus, veterans are but one subculture of a larger national memory that can be discerned from its expressions. The scholarly consensus emphasizes the political nature of such understanding of the past: collective memory is constructed, enacted and contested by a multiplicity of actors. ${ }^{28}$ The politics of cultural memory in the United States is a prime example of this - this will be discussed in part 2.

Of the many nuanced but contentious definitions of collective memory, my use of the term public memory is closest to Jan Assmann's concept of cultural memory, which denotes the ways of institutionalized remembering of (most usually) the national past. Assmann defines cultural memory as "that body of reusable texts, images, and rituals specific to each society in each epoch, whose 'cultivation' serves to stabilize and convey that society's self-image. Upon such collective knowledge [...] each group bases its awareness of unity and particularity." ${ }^{29}$ As Wulf Kansteiner subsequently elucidated, "Cultural memory consists of objectified culture - that is, the texts, rites, images, buildings and monuments which are designed to recall fateful events in the history of the collective. As the officially sanctioned heritage of a society, they are intended for the longue durée." 30 Part 3 of this article traces the deployment of such cultural memory in late Cold War US Transatlantic relations.

\section{National Memory in the United States}

As a historically diverse and dynamic albeit "imperfect" democracy, the United States is a prime example of the contested and multiple meanings of the national past. Historically, the continuing presence of the indigenous population during and after the European colonization of the continent, the Transatlantic slave trade, and immigration from Europe, Asia and Latin America have all made for subcultural collective memories that coexist as well as contend with the dominant

28 Finney, “The Ubiquitous Presence," 448; Resende and Dudryte, eds., Memory and Trauma in International Relations, 62, 63, 71-73; Langenbacher and Shain, eds., Power and the Past, 8; Bell, Memory, Trauma and World Politics, 5, 15.

29 Jan Assmann, "Collective Memory and Cultural Identity," New German Critique, lxv (1995): 126, $127,132$.

${ }^{30}$ Wulf Kansteiner, "Finding Meaning in Memory: a Methodological Critique of Collective Memory Studies," History and Theory, xli (2002): 182. 
memory regime of the white Anglo-American middle class. African American commemorative traditions range from the "Mardi Gras Indians" 31 to the celebration of Juneteenth, the anniversary of the announcement of the abolition of slavery in Texas on June 19, 1865. As a result of massive immigration, European-derived US ethnic groups including the Irish, the Italians and the Poles also exert an influence on local and regional memory. ${ }^{32}$ As Kryštof Kozák has shown, Mexican Americans have their distinct memory of the history of Texas and US-Mexican relations. $^{33}$

Just as importantly, the ideal of equality enshrined in the United States Constitution as well as the widely accepted adage that "immigrants made this nation" have also provided a point of reference and a powerful justification for the attempts of subcultural groups to reinterpret the national past based on their memory. Thus, many of the nation's subcultural and historically marginalized groups - among them African and Native Americans, women, and dissenters - have both contested and used various anniversaries of the national past to commemoratively perform their own meaning of the original event, and make claims for political, social and cultural rights. The Civil Rights Movement's 1963 March on Washington used the hundred's anniversary of the Emancipation Proclamation and the site of the Lincoln Memorial; the 200th anniversary of the Declaration of Independence saw commemorations by a so-called "Bicentennial without Colonies" coalition for social and political causes; and American Indians have been publicly counter-commemorating Columbus Day at least since the late twentieth century. ${ }^{34}$ As a result of Euro-American preferences, ethnic activism, moral imperatives, and to appeal to ethnic voters in elections, several originally subcultural anniversaries such as Columbus Day, Juneteenth, Kwanzaa and Black History Month have also been lifted or reworked into state and federal government commemorative programming.

Yet the dominant Anglo and Euro-American memory regime continues to not only define US national memory, but - through its periodic reassertion often

${ }^{31}$ See Joseph Roach, Cities of the Dead: Circum-Atlantic Performance (New York: Columbia University Press, 1996); George Lipsitz, "Mardi Gras Indians: Carnival and Counter-Narrative in Black New Orleans," Cultural Critique No. 10 (Fall 1988): 99-121.

32 John Bodnar, "The Construction of Ethnic Memory" and "Conclusion: Subcultures and the Regime," in Remaking America: Public Memory, Commemoration, and Patriotism in the Twentieth Century, by John Bodnar (Princeton, NJ: Princeton University Press, 1992), 41-77 and 245-54, respectively.

33 Kryštof Kozák, "Superiors, Victims, or Neighbors? The Collective Memory Divide between Anglos and Mexicans," The United States as a Divided Nation - Past and Present, ed. Marcin Grabowski, Kryštof Kozák and György Tóth (Frankfurt am Main: Peter Lang Verlag, 2014), 269-86.

${ }^{34}$ Sam Hitchmough, "It's Not Your Country Any More': Contested National Narratives and the Columbus Day Parade Protests in Denver," European Journal of American Culture Vol. 32, No. 3 (September 2013): 263-83. 
triggered by a perceived or actual crisis - to enact its edicts with an iron hand. Many of its official patriotic rituals and stories were developed or codified in the late nineteenth and twentieth centuries as part of US nativist efforts to "Americanize" immigrants thought to be significantly different from the Anglo-European settlers. Conservative Anglo-Americans and national leaders also responded to the appearance of leftist ideologies, the struggles of organized labor, US involvement in two world wars, and the Cold War by devising such cultural-political "litmus tests" as the rituals around the national flag, the Pledge of Allegiance, and other "invented traditions" of civil pageantry. ${ }^{35}$ Historic battlefields and the war dead in country and abroad are venerated through serious rituals not only by the national government, but also by veterans' groups, civic associations, and historical re-enactors. ${ }^{36}$ The resurgence of iron-clad patriotism bordering on intolerant nationalism as a response to the September 11,2001, terrorist attacks is but the most recent and obvious example of the continued hegemony of this national memory regime in the United States. ${ }^{37}$ Out of sincere patriotism, self or group interest, or a pressure to acculturate, most subcultural groups at least strategically subscribe to the patriotic values and rituals represented by the dominant American memory regime.

The functions of this hegemonic US national memory are predictable. Above all, the official, public history and educational version of the national past aims to maintain unity, coherence, and loyalty to the status quo in politics, society, and culture. As early as around the birth of the new nation, the British-American painter Benjamin West created pictures such as his 1770 Death of General Wolfe to remind seething elites on both sides of the Atlantic of their shared British patriotism, which had recently won a war against France. ${ }^{38}$ Painting his Washington Crossing the Delaware in 1850-51 in Düsseldorf, Germany, German-American painter Emmanuel Leutze deliberately picked the theme of patriotic courage turning the tide of the American Revolution in order to invoke the glorious past shared both by slaveholders, moderate US politicians, and abolitionists, who were now inching closer to a civil war. As David Blight has shown, by the early twentieth century veterans' reunions, popular romances and plays, and political rhetoric had managed to purge the memory of the US Civil War of its racial component, and

35 Bodnar, Remaking America; Richard M. Fried, The Russians Are Coming! The Russians Are Coming! Pageantry and Patriotism in Cold-War America (New York: Oxford University Press, 1998).

36 Edward T. Linenthal, Sacred Ground: Americans and their Battlefields (Urbana, IL: University of Illinois Press, 1991).

37 Among others, see Susan Faludi, The Terror Dream (New York: Picador, 2007).

38 Benjamin West's 1770 painting titled Death of General Wolfe depicted a scene from the Battle of Quebec in 1759, waged against France as part of the Seven Years' War. 
slavery as a cause of the conflict was erased by the official white reconciliationist remembrance. ${ }^{39}$

Even more than in other countries, another powerful player in the expressions as well as shaping of US national memory is the media and popular culture industry. Early film showed its potential to influence interpretations of history through D. W. Griffith's 1915 The Birth of a Nation, which popularized a white supremacist and reconciliationist revision of the memory of the Civil War and Radical Reconstruction. The Disney Company's Davy Crockett television series in the 1950s tapped into a yearning for guidance from the past about American values that could help US society fight the Cold War. Since the late twentieth century, historical documentaries directed by Ken Burns have powerfully shaped the ways in which Americans represent their past as well as how they understand it ${ }^{40}$ - his 1990 The Civil War aimed to create order out of the diversity of multiculturalism for his mainstream white middle class older male audience. ${ }^{41}$ In the twenty-first century, TV period fiction drama shows like Deadwood, Mad Men and Hell on Wheels use a historical epoch as a backdrop to intricate plots of social intrigue. At the same time, the major US history cable channels have come to be dominated by reality TV-style documentaries relying on low-cost re-enactments ${ }^{42}$ and often focusing on the sensational parts of history; their products such as The Deadliest Warrior have influenced the computer animation and video games, as well as popular content on the Internet.

The reigning mode of media remembrance of US history, especially of wars, is highly personalized, demands identification with characters, ${ }^{43}$ and emphasizes the everyday life and struggles of its subjects. This is combined with a demand for accuracy of detail in design and props not unlike in historical re-enactment - it is no wonder that many historical documentaries rely on re-enactment even more than the Ken Burns methods of film making. Especially evident in war movies and shows such as Saving Private Ryan and Band of Brothers, such "tyranny of details"

39 David W. Blight, Race and Reunion: The Civil War in American Memory (Cambridge, MA, London: Harvard University Press, 2001).

40 Gary R. Edgerton, "Mediating Thomas Jefferson: Ken Burns as Popular Historian," in Television Histories: Shaping Collective Memory in the Media Age, ed. Gary R. Edgerton and Peter C. Rollins (Lexington, KY: The University Press of Kentucky, 2001), 168-90.

${ }^{41}$ Gary R. Edgerton and Peter C. Rollins, eds., Television Histories: Shaping Collective Memory in the Media Age (Lexington, KY: The University Press of Kentucky, 2001), 4-5.

42 One instance where re-enactment is a positive development in historical documentary film making is the American Indian history documentary series We Shall Remain (dir. Chris Eyre, Public Broadcasting Service: 2009), in which re-enactment serves to empower Native Americans to represent their own history, and thereby also becomes an expression of their memory. For more on the film, see http://www.pbs.org/wgbh/amex/weshallremain/.

${ }^{43}$ Edgerton and Rollins, eds., Television Histories, 2-3. 
tends to privilege the immediate experience of "being there" 44 and the microhistorical struggles of the little man over critical reflection about the wider historical context, and it obscures or erases the moral dimension of history, the responsibility of political and other leaders, as well as the larger historical structures and forces that conditioned the struggle of the characters.

Yet the American popular culture industry's memory regime does not go unchallenged by the historical professions. "Traditional” entities like history museums, archives, libraries and universities have made inroads in popular history through their ingenious use of digital social media. ${ }^{45}$ Even in a narrower sense, professional historians continue to exert influence on US collective memory. Not only do they serve as consultants for documentary and nonfiction feature films, a few of them also influence the thinking of presidents. While David Blight was historical consultant for the 2012 movie Lincoln, directed by Steven Spielberg and starring Daniel Day-Lewis, in his first term President Barack Obama claimed he gave much thought to the lessons in Doris Kearns Goodwin's book Team of Rivals: The Political Genius of Abraham Lincoln.

Not unlike in other countries, the post-Cold War period witnessed intense struggles over the ideological content of expressions of memory in the United States. Veterans' groups and conservatives in politics and the media fiercely reasserted their patriotic memory regime by criticizing the critical interpretation of the role of art in the conquest of the West in the Smithsonian's 1991 exhibition titled The West as America, Reinterpreting Images of the Frontier, 1820-1920, ${ }^{46}$ as well as the perspectives of the US nuclear strike on Japan in its 1995 display Crossroads: The End of World War II, the Atomic Bomb and the Cold War. ${ }^{47}$ Over the same years, former chairperson of the National Endowment for the Humanities Lynne Cheney criticized the US history curriculum for teaching a negative view

${ }^{44}$ Edgerton and Rollins, eds., Television Histories, 3.

45 One example of the many is the Internet and digital social media use of the Special Collections and University Archives of The University of Iowa: they regularly work through a Facebook profile, Twitter, Pinterest and Tumblr account, as well as projects of digitization and "crowdsourcing" (asking Internet visitors to interactively improve content) on their own websites. Online respectively, http:// uispeccoll.tumblr.com/.

46 Stephen C. Behrendt, Review of The West as America: Reinterpreting Images of the Frontier, 1820-1920, ed. by William H. Truettner, Great Plains Quarterly 1, 1 (1992), 289-90, http://digitalcommons.unl .edu/greatplainsquarterly/652/. See also "Vox Populi" readers' comments book, New York Times, July 7, 1991, http://people.virginia.edu/ mmw3v/west/reviews/nyt_commentbook.pdf.

47 Neil A. Lewis, "Smithsonian Substantially Alters Enola Gay Exhibit After Criticism," New York Times, October 1, 1994, http://www.nytimes.com/1994/10/01/us/smithsonian-substantially-alters-enola-gay -exhibit-after-criticism.html. Also see "The Enola Gay Controversy," History on Trial. Lehigh University Digital Library, http://digital.lib.lehigh.edu/trial/enola/. 
of the national past - emphasizing the injustices committed against American minorities and other nations over the country's exceptional achievements and values of Christian faith, U.S. capitalist enterprise, democracy, technological and scientific progress, and the U.S. as a world power. ${ }^{48}$ Chilling progressive efforts to influence popular history, such attacks were part of a larger conservative revival and mobilization in politics to gain power for the Republican Party and its patriotic-nationalist ethos. ${ }^{49}$

\section{The Legacy of the Cold War for Memory in US Transatlantic Relations}

For over 40 years, the government of the United States functioned under the ideological assumptions of the Cold War, for which some of the best and the brightest of the country developed corresponding security apparatuses and operating procedures. Accordingly, American policy and decision makers as well as of the larger circles of the national elite attempted to utilize all realms of knowledge that could plausibly assist them in containing if not winning their global struggle. In order to understand the outlook of some of the power players in US government beyond the end of the Cold War, it is necessary to study their use of memory in the late phase of the global contest.

\section{Collective Memory and Decision Making}

For Patrick Finney's research focus on the role of collective memory in international decision making, ${ }^{50}$ one potential smoking gun is R.E. Neustadt and E. R. May's 1986 book Thinking in Time: The Uses of History for Decision-Makers. ${ }^{51}$ Because of the timing of its publication and its likely influence on decision making processes, ${ }^{52}$ the book bears closer examination.

48 See Lynne Cheney, Telling the Truth: Why Our Culture and Our Country Have Stopped Making Sense - And What We Can Do About It (New York: Simon \& Schuster, 1995).

${ }^{49}$ See James Davison Hunter, Culture Wars: The Struggle to Define America (New York: Basic Books, 1991); and Richard Jensen, "The Culture Wars, 1965-1995: A Historian's Map," Journal of Social History 29 (October 1995): 17-37.

50 Finney, "The Ubiquitous Presence," 452.

51 Neustadt and May, Thinking in Time.

52 What Neustadt and May called "historical reasoning" or "historical analogies" fits into my formulation of collective memory, which is comprised of personal memory, the dominant and official memory regime, the influence of the historical professions, popular culture, cultural memory, and subcultural memories. Hence I use the authors' terms to refer to memory here. 
Published in 1986 by Macmillan USA, reprinted in 1988 by Free Press, and deemed profitable enough to issue on e-readers in $2011,{ }^{53}$ Neustadt and May's book continues to be assigned in graduate-level university courses, ${ }^{54}$ and it is featured under "Leadership and Management" on the recommended reading list of the American Foreign Service Association, the professional association and labor union of both the US State Department and USAID. ${ }^{55}$ Academic and professional communities continue to find the book relevant and make it part of the expertise needed by those in high government office. Written by two professors at the John F. Kennedy School of Government at Harvard University, both of whom had also served in or worked with several presidential administrations and advised those in power or close to it, the book is as close to being a manual or policy paper for a conscious and "routine" use of historical reasoning in decision making as a document can be. In the late Cold War and the post-Communist period, Thinking in Time was used in the training of generations of people who went into public service, some of whom subsequently worked their way up to high levels of government and policy making, and are still there in the second decade of the twenty-first century. In this sense, the book offers both descriptive and prescriptive insights into the role of memory in decision making in the United States government.

To answer the question "could better routine staff work have achieved better results?" 56 the book examines a number of case studies from the 1950s through the 1980s of right and wrong decisions based on historical analogies. Yet even as they draw conclusions, Neustadt and May go beyond the usual judgment by professional historians that government does not know or use history. The authors focus

${ }^{53}$ Neustadt and May, Thinking in Time, on Barnes and Noble, http://www.barnesandnoble.com /w/thinking-in-time-richard-e-neustadt/1111508544? ean=9780029227916.

${ }^{54}$ Among others, the book is assigned as a reading in courses at the Sanford School of Public Policy, Duke University (http://www.hart.sanford.duke.edu/index.php/courses/syllabus/hist_195s.06 _-_leadership_in_american_history); the Steven J. Green School of International and Public Affairs, Florida International University (http://sipa.fiu.edu/about-us/sipa-senior-fellows-1/dexter-lehtinen /syllabus/); Tufts University (http://ase.tufts.edu/polsci/curriculum/syllabi/fall2014/ps101.pdf); the American Academy of Diplomacy (http://www.academyofdiplomacy.org/programs/Diplomacy _and_Education/AAD_Member_Course_Syllabi/Edelman\%20SAIS_Diplomatic\%20Disasters\%20 Syllabus.pdf); the School of International Relations, the University of Southern California (dornsife. usc.edu/assets/sites/32/docs/IR_341_Fall14_Syllabus-2.doc ); the School of Policy, Government, and International Affairs, George Mason University (http://spgia.gmu.edu/wp-content/uploads/PDFs /Syllabi/2014/Fall/PUBP/Rhodes-PUBP700-006-Fall-2014.pdf); the University of Colorado at Boulder (http://www.colorado.edu/history/chester/IAFS1000Syllabus2006.htm); and Oberlin College (http://new.oberlin.edu/dotAsset/1713746.pdf).

55 Recommended reading list. American Foreign Service Association, http://www.afsa.org/Publications Resources/FSReadingList/AFSARecommendedReading.aspx.

${ }^{56}$ Neustadt and May, Thinking in Time, xiii-xv, 3. 
on formulating micro-procedures for even marginally better results in decision making, working within the confines of contingency situations at the highest levels of government. Accordingly, the book recommends a to-do list of fast background research and conceptual moves that lead to better situation assessment, options and decisions.

Neustadt and May's criticism of the usual use of historical reasoning in decision making is not that government officials do not use analogies from the past - it is that they use them without adequate reflection and without questioning their appropriateness for the current situation. Most such situations begin with a crisis that requires an urgent response, which forces decision makers into a reactive position. Leaders are often tempted to use historical analogies as shorthand for the complex current scenario - regardless of their appropriateness for it. Combined with the pressure to act, such ready-made parallels make careful deliberation difficult. ${ }^{57}$ The authors' lessons from successful decision making show that careful reflection and an examination of the presumptions of historical parallels and proposed options tend to yield better policy results. For example, Secretary of State Dean Acheson intervened in the Kennedy cabinet's deliberations during the Cuban Missile Crisis by explaining why the current situation was not analogous to the Japanese attack on Pearl Harbor, causing the president's war council to change their positions. ${ }^{58}$

Among others, successful decision makers ask about the history and memory of their and their adversaries' institutions and well as persons, thus arraying for patterns of behavior that can be used to predict actions and reactions in the current crisis. At the same time, such leaders also envisioned their own challenge on a time line of the history of the topic at hand. ${ }^{59}$ Neustadt and May illuminate that what often allows for better decision making is buying time for careful deliberation and keeping policy options open.

In their book, Neustadt and May paint a revealing picture of the culture of those in power. Leaders do not usually think about history for their own decisions; they have little time to focus on an issue even when it presents them with a crisis; and their decisions are mostly reactive, aimed at alleviating crises and averting disasters, thus postponing rather than permanently resolving problems. Yet it is precisely such dynamic that would call for a formulation of a policy for the use of memory in diplomacy. A memory policy would provide the conceptual as well as

\footnotetext{
57 Neustadt and May, Thinking in Time, 4-5.

58 Neustadt and May, Thinking in Time, 7.

59 Neustadt and May, Thinking in Time, 235-36, 238, 246.
} 
material (deliberative/advising, communicative, implementation) infrastructure and personnel to go beyond reactive work, and into a proactive mode.

Neustadt and May's study of the use of historical reasoning in decision making is tempting to apply for late Cold War US foreign policy and beyond. Yet the authors themselves reveal some of the methodological pitfalls of their own framework. For example, while the transcripts of the Kennedy deliberations over the Cuban Missile Crisis show references to Pearl Harbor and Suez, no one mentioned any earlier historical periods - yet in the president's official speech he referred to the "clear lesson" of the appeasement policies to Nazi Germany in the 1930 s. ${ }^{60}$ This shows how difficult it is for scholars of the use of memory in government to verify claims in the absence of accessible contemporary internal documents. Political speeches like Kennedy's and public diplomacy materials like those issued by the US State Department use collective memory rhetorically, but they do not readily yield insights into the dynamic of government decision making or formulations of policy.

Some scholars have cautiously applied Neustadt and May's framework for post-1990 US decision making, ${ }^{61}$ notwithstanding the methodological questions that plague the project. As William Inboden has shown, President Bush the elder used the 1938 Munich Agreement to understand the situation between Iraq and Kuwait in 1990 and decide for US intervention - both in a speech in Prague and in a private letter. Bush also referred to the lessons of the US involvement in Vietnam for the first Gulf War in his diaries. ${ }^{62}$ Confronted with the new global political landscape after the end of the Cold War, the Clinton administration looked to the aftermath of World War Two and early Cold War for blueprints to set up international organizations. ${ }^{63}$ Scholars have also shown how Secretary of State Madeline Albright's memory of Munich informed the Clinton administration's public position on the war in Kosovo in $1999 .{ }^{64}$ For his own part,

During his presidency, [George W.] Bush frequently invoked the Truman administration's strategic posture during the early Cold War years as precedents for the Bush

\footnotetext{
${ }^{60}$ Neustadt and May, Thinking in Time, 8.

${ }^{61}$ One fascinating use of Neustadt and May's study is its application to cyber security threats. See David Sulek and Ned Moran, "What Analogies Can Tell Us About the Future of Cybersecurity," Policy paper. NATO Cooperative Cyber Defence Centre of Excellence, http://www.ccdcoe.org/publications/virtual battlefield/08_SULEK_What\%20Cyber\%20Analogies\%20Can\%20Tell\%20Us.pdf.

${ }^{62}$ William Inboden, "Statecraft, Decision-Making, and the Varieties of Historical Experience: A Taxonomy." Journal of Strategic Studies Vol. 37, No. 2 (2014): 291-92.

63 Inboden, "Statecraft, Decision-Making, and the Varieties," 308-9.

64 Paris, "Kosovo and the Metaphor War," 435, 437.
} 
administration policies in the Global War on Terror. For example, in his [...] West Point commencement address, Bush drew the Truman parallels at great length. These were not limited to public rhetoric. Bush also privately studied Truman's presidency, and saw in Truman's persona and challenges numerous parallels to his own. These included a populist diction style, low approval ratings, an unpopular localized hot war amidst a global ideological conflict, disputes with Congress and the Supreme Court over executive authority, efforts to forge new domestic and international institutions to address the prevailing security threat, and confidence in the eventual vindication of history. 65

Inboden not only supports his analysis with evidence from contemporary newspaper accounts and scholarly treatments, but also cites Bush's memoir. Yet much of this may still be interpreted as public relations, government rhetoric or retrospective justification by a leader of his own decisions in order to shape his own historical legacy - if it wasn't for the fact that Inboden himself had "also worked on the National Security Council staff from 2005-2007, and responded to Bush's interest in Truman by writing multiple memos drawing on the lessons of the Truman presidency." 66 However, without such internal evidence, such studies lack verifiable data about memory in policy making.

Thus, even as Neustadt and May's study illuminates the internal dynamics of high-government decision making, their model is difficult to apply in recent historical or current scholarship. Hence, instead of studying its role in policy making, it is more feasible to examine the uses of collective memory in Transatlantic relations. Since many relevant Cold War US government documents are still inaccessible, ${ }^{67}$ the remainder of this article attempts to "reverse engineer" traces of US memory policy from declassified government papers as well as public diplomacy

65 Inboden, "Statecraft, Decision-Making, and the Varieties," 309.

66 Inboden, "Statecraft, Decision-Making, and the Varieties," 309.

67 The National Archives "has generally not yet accessioned records dated after the mid-1970s, although in some cases there are records dating to 1999." Records of the U.S. Information Agency (RG 306). Cold War Era Agencies. National Archives, http://www.archives.gov/research/foreign-policy/related-records /rg-306.html. The Department of State "Central file records dating 1980 and later remain in the custody of the Department of State. Researchers must file a Freedom of Information Act (FOIA) request directly with the Department to request access to records in their custody." Central Files 1973-1979: State Archiving System (SAS)(RG 59). Department of State Records. National Archives, http://www.archives.gov /research/foreign-policy/state-dept/rg-59-central-files/1973-1979.html. The Bureau of Educational and Cultural Affairs Historical Collection was donated to the University of Arkansas by the United States Information Agency in 1983. Bureau of Educational and Cultural Affairs Historical Collection (CU) Records, ca. 1938-1984. University of Arkansas Liberaries Special Collections, http://libinfo.uark.edu /SpecialCollections/findingaids/cuaid/. 
materials. Accordingly, its findings will be preliminary, pending the fuller declassification of internal government documents.

\section{The Cold War Apparatus for Memory Policy: The United States Information Agency}

Building the material infrastructure and human bureaucracy of the Cold War took decades, and its structures predictably survived for years after the end of this ideological world system. Accordingly, for much of the 1990s, the United States government had in place an apparatus for the use of memory in its Transatlantic relations.

Among the many tools the United States government used during the Cold War to win the hearts and minds of those living in the developing world and counter Communist propaganda was American history. Scholars like Richard Pells have discussed the ways in which American Studies, the academic study of US history, culture and society, was transplanted in Europe through the educational diplomacy of the US government's Fulbright Program, professional organizations, and private foundations. ${ }^{68}$ Yet academia is only one player or mechanism in the larger dynamic of the politics of collective memory within and between countries. The US government used cultural memory in its programming which commemorated various anniversaries of the national past - as a way to support its foreign policy objectives. In the late Cold War and beyond, most such programming was carried out by three government agencies: the United States Information Agency, the Department of Defense, and commemorative presidential commissions.

Created in 1953 by presidential executive order, the United States Information Agency (called "Service" at its end points overseas; henceforth USIA/S) was to centrally conduct the US government's previously disparate foreign information activities. ${ }^{69}$ In 1978 another presidential order merged USIA/S with the State Department's Bureau of Educational and Cultural Affairs ${ }^{70}$ into a new entity called the United States International Communications Agency. In 1982 the agency was

68 See Richard Pells, "American Studies in Europe," in Not Like Us: How Europeans Have Loved, Hated, and Transformed American Culture Since World War II, by Richard Pells (New York: Basic Books, 1997), 94-133; also Michael Denning, “The Special American Conditions': Marxism and American Studies," in Culture in the Age of Three Worlds, by Michael Denning (London, New York: Verso, 2004), 169-92.

69 See Richard Arndt, “The Birth of USIA," in The First Resort of Kings: American Cultural Diplomacy in the Twentieth Century, by Richard T. Arndt (Washington, D.C.: Potomac Books Inc., 2005), 264-87.

70 History and Mission of ECA. Bureau of Educational and Cultural Affairs. United States Department of State, http://eca.state.gov/about-bureau/history-and-mission-eca. 
rechristened to its original name, which it used until is abolition in 1999, when its media functions, including the Voice of America, were assigned to the State Department and the International Broadcasting Bureau. ${ }^{71}$ In a regretful act of shortsightedness, the US government's primary arm of cultural diplomacy, the USIA/S was dismantled just two years before the September 11, 2001, terrorist attacks, which prompted the government to put in place a new apparatus for public diplomacy. ${ }^{72}$

After its 1978 reorganization, USIA/S was a government agency with formidable activities. Every year, its Fulbright program gave out some 5000 grants for sending overseas or bringing to the United States individuals for teaching or academic study. Its equivalent for non-academic professions, the International Visitors Program facilitated the trips to the US of some 2000 people every year. Like US public diplomacy in general, both of these programs targeted foreign elites and would-be elites (most often students or vocational apprentices) in order to mold their attitudes towards the United States both in their own professions and more generally, as a geopolitical player. In this, they were assisted by USIA's English teaching and book programs, as well as its actual facilities overseas: embassy libraries, America houses and other cultural centers, with their own programming. USIA/S also facilitated the tours of art exhibitions and performing artists overseas, including in Eastern Europe and the USSR, as well as in the third world. ${ }^{73}$

The Reagan administration not only gave the agency its old name back, but it also updated it in its own image. In keeping with the resurgence of hard line anti-Communism in US foreign policy, the USIA/S was to shift back from being a facilitator of international cultural exchange and democratic dialog to being an instrument of US overseas propaganda, and a weapon for winning the Cold War. ${ }^{74}$ Accordingly, with increases in funding, the agency launched Radio (and later TV) Martí, targeted at Cuba; it implemented Worldnet, a satellite linkup for policy discussions between US and foreign government officials; and it modernized the technology of the Voice of America. ${ }^{75}$ The institution's overseas libraries were con-

71 Records of the U.S. Information Agency (RG 306) description. Cold War Era Agencies. Foreign Affairs. National Archives of the United States, http://www.archives.gov/research/foreign-policy /related-records/rg-306.html.

72 Also see Christopher Merrill et al., Cultural Diplomacy: The Linchpin of Public Diplomacy. Report of the Advisory Committee on Cultural Diplomacy. Washington, D.C.: U.S. Department of State, September 2005, http://www.state.gov/documents/organization/54374.pdf.

${ }^{73}$ Richard T. Arndt, The First Resort of Kings: American Cultural Diplomacy in the Twentieth Century (Washington, D.C.: Potomac Books Inc., 2005), 521, 524.

74 Arndt, The First Resort of Kings, 527, 532.

75 Arndt, The First Resort of Kings, 527. 
verted into Information Resource Centers, equipped with electronic apparatuses, but were also guarded by heavier security and a requirement of appointments for visitors. Both the Fulbright and the International Visitors Program came under more control and ideological programming; and USIA/S inaugurated a new program to bring high school students to the US for one year to win them over for democracy before their ideological positions hardened. ${ }^{76}$ Meanwhile, responding to ideological disagreements with a suspension of multilateral cultural exchange, the United States officially withdrew from the United Nations Educational, Scientific and Cultural Organization, pulling a quarter of UNESCO's operating budget. ${ }^{77}$

In order to understand how USIA "projected" American collective memory around the world, it is important to know the sources of its materials. Passed by US Congress in 1948, the so-called Smith-Mundt Act forbade government materials designed for foreign consumption to be disseminated within the United States, in order to prevent the government from propagandizing its own population. The law, however, still allowed materials originally designed for domestic consumption to be used in overseas cultural diplomacy. This meant that USIA/S could both produce brand new materials and use the visuals, documents, films, exhibitions produced domestically and disseminate them overseas, however much adapted to their different audiences and circumstances.

\section{The Bicentennial of the United States Constitution in US Transatlantic Cultural Diplomacy}

A USIA report from this period provides a window into how the agency worked in tandem with a presidential commission to use collective memory as part of its cultural and public diplomacy activities. The Commission on the Bicentennial of the U.S. Constitution was established in September of 1983 by the US government

76 Arndt, The First Resort of Kings, 529. The US government's cultural and educational programs for high-school age youth overseas were a response to the upheavals of the 1960s and especially the "global" 1968, in which student activism challenged not only their own national hierarchies and norms, but also articulated criticism of US foreign policy. For more, see "Student Protest and International Relations," in The Other Alliance: Student Protest in West Germany and the United States in the Global Sixities, by Martin Klimke (Princeton, NJ: Princeton University Press, 2010), 194-235.

77 Arndt, The First Resort of Kings, 534, 531-32. Also see "Communication from the Secretary of State of the United States of America Concerning the Withdrawal of the United States of America." Item 5.1 of the agenda. Hundred-and-nineteenth Session. United Nations Educational, Scientific and Cultural Organization Executive Board. Paris, May 11, 1984, http://unesdoc.unesco.org /images/0005/000595/059531eo.pdf; “Text of Statement by U.S. on its Withdrawal from UNESCO," The New York Times, December 20, 1984, http://www.nytimes.com/1984/12/20/world/text-of-statement -by-us-on-its-withdrawal-from-unesco.html. 
in order to plan activities commemorating the September 17, 1787, signing of the United States Constitution, the formation of the three branches of government, and the subsequent addition of the Bill of Rights to the nation's foundational legal document. Headed by former Supreme Court Chief Justice Warren E. Burger, the Commission had some twenty members, and commanded considerable prestige. The most logical partner for the Commission's overseas initiatives was the United States Information Agency, the government's propaganda and cultural diplomacy arm. As USIA's late 1987 "Four-Year Review Update" explained,

The foundations of the Bicentennial of the Constitution programming were laid in 1984 and 1985. Beginning in 1986, on-going [USIA/S] programs such as the International Visitor, Youth, Teacher, and Fulbright exchange programs and the Book and Library programs began to include a Constitutional component. In addition, overseas posts and USIA Washington elements have developed special seminars, conferences and publications designed to maximize the impact of the Bicentennial abroad and to increase knowledge and understanding of American culture and society in the context of our governmental system. ${ }^{78}$

While the Commission on the Bicentennial of the U.S. Constitution was mandated by Congress to coordinate commemorative activities, most such programming outside of the country was implemented as well as designed by the United States Information Agency, the cultural diplomacy arm of the US government. Thus, USIA/S received a second-hand mandate from the Commission for overseas commemorative programming - which it did first by incorporating and foregrounding the US Constitution in its already existing programs, and subsequently by having its posts and offices design new activities with a more exclusive constitutional focus.

While the agency's programs extended hemispherically to the Americas as well as to world regions such as Africa, the Middle East, the Pacific and south Asia, the geographical foci of its Transatlantic activities were the North European countries (the United Kingdom and the Republic of Ireland), the region of Central and Southern Europe (West Germany, Switzerland, Italy, Spain), with incursions made into the West (France), the Eastern Bloc (Poland, Romania), and the nonaligned

78 Mark Blitz, "Four-Year Review Update" of the Bicentennial of the United States Constitution programming. Memorandum for the director of the United States Information Agency. October 20, 1987. In "Report on Worldwide USIA Activities to Commemorate the Bicentennial of the U.S. Constitution." Commission on the Bicentennial of the U.S. Constitution. Office of Federal and International Programs. National Archives at College Park, Maryland. 
world (Serbia in Yugoslavia). Countries that received considerable attention in USIA/S commemorative programming because of their special geopolitical importance to the United States were the old Transatlantic ally Great Britain, the Cold War's "frontline" country of West Germany (the youth of which had become more critical of the US since the 1960s), Italy, which had a strong political left, and Spain, which had been transitioning from General Franco's dictatorship to democracy since 1978. Attendees of the commemorative events came from these countries as well as others in and outside Europe.

The target audiences of USIA/S commemorative programming were the respective host countries' elites: academics, educators, lawyers, journalists, government officers and politicians, and university and high school students. (One prototypical example for this was a special course at Madrid University exclusively devoted to the bicentennial of the US Constitution.) The highest-ranked guest in attendance was British Prime Minister Margaret Thatcher, who was also awarded a prize of recognition for her public service. ${ }^{79}$ USIA's bicentennial programming reached hundreds of the national elite in each country directly - and thousands more through literature, as well as tens of thousands more through media coverage. ${ }^{80}$

Funding for the commemorative programming of the bicentennial of the US Constitution came from the Commission, USIA, private donors (e.g. Italian banks), professional bodies, and educational institutions like the University of Bologna. Activities also received in-kind assistance from foreign governments, which hosted receptions and events with a diplomatic profile in their own facilities. (Events were otherwise mostly held either at US embassy and USIA/S libraries and centers, or at university centers.) The magnitude of the funds spent on commemorative programming is suggested by some examples. Its Paris post requested from USIA's educational and cultural bureau a grant of 15,000 USD for a conference on the current status of US civil rights (voting, education and employment), which was to be co-sponsored by relevant departments of the University of Paris. USIA's Dublin post received 10,000 USD from the Fulbright program's 1987

79 "Embassy Commemoration of the Constitution Bicentennial." American Embassy London cable to USIA Washington, D.C., September 1987. In "Report on Worldwide USIA Activities to Commemorate the Bicentennial of the U.S. Constitution."

80 One Spanish TV program's viewership was an estimated 750,000 people. Like those of any other government office, the reports of the United States information Agency were produced with a subtext that attempts to justify and argue for continued funding for the activities of the authors; thus, their perspective is self-celebratory and has a potential for overstating their reach and effectiveness. "Report on Worldwide USIA Activities to Commemorate the Bicentennial of the U.S. Constitution." 
budget to organize a commemorative academic colloquium with the Irish Association for American Studies in Galway. ${ }^{81}$

USIA needed this money not only for its events but also for the materials it produced and distributed in its programming. The agency's repertoire included an impressive array of types of products and media, most of which was mass-produced or replicated for its overseas posts. The USIA created and shipped abroad a number of copies of its poster show, a book exhibit, a variety of old and new book translations, bibliographical guides, professional journal issues, video tapes for schools, its TV broadcasts made for VHS tapes and aired on satellite linkup, and it planned a BBC documentary series for the 1988 presidential elections. ${ }^{82}$

In the Commission's alliance with USIA, Justice Burger especially used his professional network to mobilize the legal and academic world for overseas commemorative programming. Commemorative speakers were mostly US academics and legal experts, high court justices and clerks, as well as their European counterparts, especially university professors of American Studies from a variety of disciplines, especially Political Science. The fields and topics of the US Constitution's bicentennial commemorative events reflected both Justice Burger's interests and USIA's foci in Transatlantic cultural diplomacy. Predominant in the programming were academic and processional conferences in the fields of History, Political Science, Constitutional Law, and related disciplines in the Social Sciences and Public Administration. The bicentennial's major topics in focus were The Federalist Papers, federalism, regionalism, the religious conscience in the US Constitution, the Constitution and party politics, elections, the presidency, Supreme Court cases about contemporary issues, the Court's schools of interpretations of the Constitution, the Constitution's influence on European law and integration (e.g. "comparative U.S.-Italian constitutional law"), and civil and human rights.

The bicentennial celebrations' structure was dominated by professional and academic events. These included academic-style conferences, professional development seminars and symposia such as the 1987 Salzburg Seminar in American Studies, and "representational events," i. e. receptions at diplomatic posts and foreign governments. It is unclear how open these events were to the public at large - especially since most were likely only by invitation, involved serious literature for distribution to attendees, and featured mostly academic and professional speakers and attendees. The academic practice of respondents giving feedback on the lectures sounds democratic on the surface; however, in many cases this likely

81 "Report on Worldwide USIA Activities to Commemorate the Bicentennial of the U.S. Constitution." 82 "Four-Year Review Update." 
consisted of nothing beyond a colleague's accolades and intellectual posturing, filling time that otherwise could have been spent with open general questions and answers, or undirected discussion.

For over three decades, USIA/S had been the overseas propaganda and cultural diplomacy arm of the United States, and its style and content of messaging reflected its goals: to counter anti-US propaganda, persuade foreign audiences to become allies and adopt US-style democracy and capitalism wholesale, and to "manage" the "image" of the United States abroad. A predictable rhetorical trope serving this purpose was the presentation of the past as the genealogy of the present and a guidepost for the future: "Celebrating our common heritage flagged the fact that we share common interests in the contemporary world." Accordingly, USIA's commemorative conferences in West Germany "reinforced the basic theme of shared values" between two countries which had waged two world wars against each other, and had recently emerged from a rather lopsided postwar relationship of "re-education" or "reorientation." In London, on the other hand, the launching of a fund-raising campaign for the restoration of the Benjamin Franklin House was a way of "highlighting the common roots of Anglo-American heritage, and could serve as an important center for cooperative programming by the embassy." 83

Yet USIA/S posts tailored commemorative communication to their needs and special circumstances in each country. USIA programming in West Germany especially reached out to "left-of-center" elites, described as "knee-jerk critics of the United States." The agency's Munich post had been trying for years to "counter [...] left-of-center stereotypes of American society, values and domestic policies." Now the post used the Constitution bicentennial's commemorative conference to engage the "Bavarian left" about a common US-West German foreign/security policy - to emphasize their "common democratic traditions which lead to common foreign policy goals." Likely recalling the West German students' anti-Vietnam movement of the 1960 s and 1970s, ${ }^{84}$ "U.S. Minister in Berlin John Kornblum [...] made an eloquent speech warning that younger generations on both sides of the Atlantic no longer looked to the past to moor the Atlantic Alliance, but must seek common interests in the multi-polar world." Yet the West German posts' report of their programming remained fundamentally defensive: "the twelve Americans who attended the conference served as

83 "Report on Worldwide USIA Activities to Commemorate the Bicentennial of the U.S. Constitution."

84 See Martin Klimke, The Other Alliance: Student Protest in West Germany and the United States in the Global Sixities (Princeton, NJ: Princeton University Press, 2010). 
resource people to counter much of the stereotype[d] arguments that are the hallmark of German leftist debate." 85

Several USIA/S country posts remade the commemorative topics according to their host country's interests, and possibly also engaged in some US domestic politics in the process. The US Embassy in Dublin used Fulbright money to jointly hold a commemorative academic colloquium with the Irish Association for American Studies, titled "The Place of Minorities in American Society." In their request for a serious grant for a gathering with the theme of "What is the State of Civil Rights in the U.S. Today," the Paris post argued that "[a]s the conference will stress the legal remedies available for the redress of grievances in these areas, it has particular relevance to the celebrations commemorating the bicentennial of our Bill of Rights, the French Revolution, and, in particular, the Declaration of the Rights of Man and the Citizen." 86 The post's proposed list of US participants was so heavy on civil rights organizations and activists that a researcher might wonder if the program was put together by a progressive embassy worker partly to spite the conservative Reagan administration by showcasing its less then sterling civil rights record in a country whose citizens had a tradition of criticizing the United States.

According to scholarly consensus, US and Western collective memory is contested ground in that it is often used by the commemorative actors to wage struggles over current issues by making meaning of the past. ${ }^{87}$ As a foundational text that continues to shape and be shaped by contemporary events, the history of the United States Constitution lends itself especially well to such commemorative dynamic. In this sense, the running subtext of the bicentennial of the US Constitution's celebrations consisted of US foreign policy (Reagan's hard-line anti-Communism and its overt and covert operations), and domestic political developments (in addition to the Iran-Contra scandal, Reagan's failed nomination of Robert Bork for the United States Supreme Court). ${ }^{88}$ Not surprisingly, USIA/S personnel, US and European

85 "Tutzing Conference on Bicentennial of the Constitution." American Embassy Bonn (and post in Munich) cable to USIA Washington, D.C., August 6, 1987. In "Report on Worldwide USIA Activities to Commemorate the Bicentennial of the U.S. Constitution."

86 "Request for Grant for October 1988 Conference on Civil Rights." American Embassy Paris cable to USIA Washington, D.C., December 1987. In "Report on Worldwide USIA Activities to Commemorate the Bicentennial of the U.S. Constitution."

87 Finney, “The Ubiquitous Presence," 448; Resende and Dudryte, eds., Memory and Trauma in International Relations, 62, 63, 71-73; Langenbacher and Shain, eds., Power and the Past, 8; and Bell, Memory, Trauma and World Politics, 5, 15.

88 The time period of the Constitution's bicentennial celebrations (1984-88) coincided with a variety of significant events in US domestic politics and foreign policy. News about the Reagan Administration's Iran-Contra operations broke in November 1986, and the Tower Commission began conducting its investigation of the National Security Council in December, and published their findings 
speakers, and foreign media and audiences used the Constitution's bicentennial to discuss the recent issues and events in US society and foreign policy.

Some commemorative actors addressed current issues quite explicitly. Several open discussions related the US Constitution to recent political events (1984 elections, Supreme Court cases), and treated the central law as a flexible and living text, which enables a self-correcting mechanism in US government. The US consul general in Zurich, Switzerland, at the 1987 commemorative reception at his residence "referred to the two principle themes in Washington this summer, the Iran-Contra hearings and the nomination of a new Supreme Court justice in which the fundamental question of checks and balances between the executive and legislative also figured into the political discussions." 89 At USIA's commemorative academic colloquium with the Irish Association for American Studies, held on Galway and titled "The Place of Minorities in American Society," one US speaker discussed the importance of the Senate confirmation hearings and rejection of Robert Bork for the post of Supreme Court justice. ${ }^{90}$ At a week-long international university seminar on the Constitution's bicentennial in Spain, Stanford University American Studies professor Jack Rakove argued that the Vietnam war resulted in shifts in the constitutional framework for US foreign policy, and he explained the intricate dynamic of policy making. ${ }^{91}$ Sometimes the most trenchant criticism of the recent past and present came from US participants who could not be controlled by USIA/S. At the 1987 Tutzing Conference on the Bicentennial of the US Constitution, "former Senator George McGovern [...] argued that virtually all U.S. presidents since WWII ha[ve] violated the [C]onstitution through illicit military interventions. His speech launched a debate on the limits of U.S. executive

in February 1987. Committees in the US House of Representatives and Senate held hearings on the topic between May and August 1987, and published a joint report in November of that year. President Reagan nominated Robert Bork for the United States Supreme Court in July 1987, which was followed by long and intense debate in the Senate, and confirmation hearings in the Judiciary Committee. After a firestorm of opposition, Bork's nomination was rejected by the United States Senate in late October 1987.

89 "Media Reaction: Celebration for the U.S. Constitution in Zurich." American Embassy Bern cable to USIA Washington, D.C., September, 1987. In "Report on Worldwide USIA Activities to Commemorate the Bicentennial of the U.S. Constitution."

90 "Celebrating the Bicentennial of the Constitution." American Embassy Dublin cable to USIA Washington, D.C., December, 1987. In "Report on Worldwide USIA Activities to Commemorate the Bicentennial of the U.S. Constitution."

91 "Bicentennial of the U.S. Constitution Amparts." American Embassy Madrid cable to USIA Washington, D.C., September, 1986. In "Report on Worldwide USIA Activities to Commemorate the Bicentennial of the U.S. Constitution.” 
power in foreign affairs." 92 At their best, such conferences provided a forum for an open and critical discussion of current issues as rooted in the past.

Yet even such open debate on the relevance of the past for the present had to be conducted on the terms of the organizers and US participants. The USIA post from Milan reported that the conference in Trieste and Padova featured Italian experts who were intimately familiar with the US system of constitutional law, and they also followed it to be able to apply some of its elements in their own legal system. ${ }^{93}$ One of the few conflictual exchanges mentioned in the record involved an attendee's public criticism of the US government's foreign policy in Nicaragua and Grenada. Dubbed a "far-leftist member of the Bologna city council" by the US post in Florence, Italy, the attendee had to be "ejected" from the conference. The speaker attempted to save the situation by ascribing the criticism to the open nature of US and Western democracy ${ }^{94}$ - a rather dubious response after the physical exclusion of this dissenting voice from this "open" commemorative event.

Questions and comments by attendees and the host countries' national media often expressed concerns about local issues as much they reflected on the past and present of the United States, or critiqued its role in the world. An Irish expert who had authored a British study on job discrimination in Northern Ireland said that US anti-discrimination legislation was applied as a model in recent UK policies against sex-based discrimination in hiring. He claimed that recently the UK and some other European countries had been more progressive than the US in such anti-discrimination legislation - likely referring to the demise of the Equal Rights Amendment in the state-by-state ratification process in the United State earlier in the decade. ${ }^{95}$ Spanish TV asked a US speaker questions about the death penalty in the US, the advantages of the jury system, and how the law protects US citizens

92 "Tutzing Conference on Bicentennial of the Constitution." American Embassy Bonn (and post in Munich) cable to USIA Washington, D.C., August 6, 1987. In "Report on Worldwide USIA Activities to Commemorate the Bicentennial of the U.S. Constitution."

93 "Bicentenary of the Constitution: Program at U of Trieste and Padova." American Embassy Rome cable to USIA Washington, D.C., December, 1987. In "Report on Worldwide USIA Activities to Commemorate the Bicentennial of the U.S. Constitution."

94 "Bicentennial of the Constitution: Report on Bologna Conference on the Constitution and What It Means Today, May 27-29, 1987." American Consul in Florence cable to USIA Washington, D.C., June, 1987. In "Report on Worldwide USIA Activities to Commemorate the Bicentennial of the U.S. Constitution."

95 "Celebrating the Bicentennial of the Constitution." American Embassy Dublin cable to USIA Washington, D.C., December, 1987. In "Report on Worldwide USIA Activities to Commemorate the Bicentennial of the U.S. Constitution." 
from "political abuses." ${ }^{6}$ These questions may have especially resonated with audiences in a country that had transitioned out of General Franco's dictatorial rule only a decade earlier.

Other voices expressed an anxious desire to keep the US government involved in European affairs. In Spain, the bicentennial programming were organized by national professional and academic bodies, who requested a few American speakers from the US embassy. After the conference on the US Constitution in Trieste and Padova, the USIA/S post from Milan reported that "the mayor of Trieste thanked USIS for staying on in the city and expressed hope that the U.S. consulate in Trieste, which was closed a year ago, would reopen." 97 According to the post's report, Italian lawyers and academics likewise praised the series of commemorative academic conferences sponsored or organized by USIA/S.

The ultimate subtext of the Bicentennial of the United States Constitution was one of the very bedrocks of Western democratic political systems: the rule of law. Thus, in their commemorative activities, participants struggled over the meaning of the history of American rule of law in the present, and its implications for the future of the United States, its Transatlantic relations, and their own European countries: they debated the overarching question of whether, how long and in what form can the rule of law endure in the United States, as well as in the countries who had developed or adopted political or legal systems similar to or different from, the United States Constitution.

The perennial question of how to measure the impact of cultural diplomacy is always most burning for those who have to justify continued or increased funding for it, and USIA's late Cold War reports grappled with this challenge. The agency used a variety of ways to measure the success of its commemorative programming: their yardsticks included the events' reach; the quality of the academic and professional conferences, especially of their discussions; the level of the event's profile; and the composition and ideology of its participants and attendees. USIA's success can also be measured with its potential for influence among the elites (academics, opinion and policy makers, legal experts) and its trickle-down among students of university and secondary school age. While quantitative stock taking would involve the numbers of people who moved across the Atlantic on US

\footnotetext{
96 "Bicentennial of the U.S. Constitution Amparts." American Embassy Madrid cable to USIA Washington, D.C., September, 1986. In "Report on Worldwide USIA Activities to Commemorate the Bicentennial of the U.S. Constitution."

97 "Bicentenary of the Constitution: Program at U of Trieste and Padova." American Embassy Rome cable to USIA Washington, D.C., December, 1987. In "Report on Worldwide USIA Activities to Commemorate the Bicentennial of the U.S. Constitution."
} 
cultural diplomacy program in any given period, qualitative measures would size up the advancement of these same people - such as the alumni of the Fulbright program - into national positions of power, and their public professional or political position vis-à-vis United States foreign policy. This highlights the networks which educational and cultural exchange programs build. The commemorative events allowed one US speaker in Spain to reunite with an old friend who had just been declared first in line for the leadership of Spain's major opposition conservative party. After their private council, the speaker briefed the embassy about the meeting and his knowledge of the politician. ${ }^{98}$

Another measurable example of the impact of USIA's commemorative programming was a 7-page article in the major independent Polish Tygodnik Powszechny newspaper in 1986 - with no apparent government censorship. The article's author claimed that in their Constitution, "Americans first of all stated the conviction that there are certain indispensable human rights that no government, under any pretext, has any power to question. [...] The state, with all its institutions, cannot therefore exceed the boundaries of its carefully limited authority. [...] Every person has the unquestioned right to decide matters which affect him, either directly or through his representatives; a government which is not elected is always usurpation and tyranny." 99 "The bicentennial of the American constitution has meaning not only for citizens of the USA but equally so for all those all over the globe for whom the ideals of freedom, equality, democracy and respect for human rights are dear. [...] As a result of the Revolution, that American message became understandable for everyone: liberty, human rights, equality of opportunity." In the conclusion of the article, the author emphasized the uniqueness of the American circumstances, and left it open to interpretation whether their Constitution can be applied as a model abroad - even as he noted its influence on the Polish constitution of $1791 .{ }^{100}$ Whether in collusion with the US Embassy or as a spokesperson of the democratic opposition emerging with Solidarity, the author used the occasion of an anniversary in another nation's collective memory to articulate grassroots demands for democratic freedoms and rights - and implicitly against the Polish Communist regime.

\footnotetext{
98 "FY-87 Ampart Albert Blaustein." American Embassy Madrid cable to USIA Washington, D.C., December, 1986. In "Report on Worldwide USIA Activities to Commemorate the Bicentennial of the U.S. Constitution."

99 "Bicentennial of American Constitution." American Embassy Warsaw cable to USIA Washington, D.C., July, 1987. In "Report on Worldwide USIA Activities to Commemorate the Bicentennial of the U.S. Constitution."

100 Ibid.
} 


\section{Conclusion}

Even a cursory case study such as this indicates that the apparatus most readily available and skilled at using collective memory in late Cold War US Transatlantic relations was the State Department's United States Information Agency/Service. USIA/S worked in partnership with the government-appointed Commission on the Bicentennial of the U.S. Constitution. Whether or not the US government or the Commission had a general and overarching policy for the use of collective memory in foreign policy, USIA/S undertook this task first by incorporating the Constitution's bicentennial to its ongoing programming, and subsequently by designing, creating and implementing new cultural diplomacy activities with a specific constitutional focus. USIA Washington and its overseas country posts had significant freedom in tailoring such programming to the special circumstances of each host country, as well as to the needs of US diplomacy there. In its commemorative programming, USIA targeted the host countries' political/government, academic and professional elites, as well as their university and high school students. USIA's bicentennial materials, conferences, seminars, and receptions emphasized the importance of the United States Constitution not only for the democratic political evolution of the American system, but also for its comparative influence on various European countries' legal and political mechanisms. While the public diplomacy messages of these bicentennial celebrations often relied on the trope of their shared past and values as the reason and impetus for their current and future alliance, both US and host country actors used the US Constitution's past to take measure and make meaning of the present struggles in their own countries as well as of the Transatlantic partnership. The ultimate subtext of the US Constitution's bicentennial celebrations was how much American rule of law endured, and how much it could be replicated in the Transatlantic realm.

This article surveyed the existing scholarly literature on the role of collective memory in international, and more specifically, Transatlantic relations. In order to develop a framework to study the uses of the national past in US Transatlantic diplomacy in the Cold War and beyond, I critiqued the methodologies of some scholars, and sketched out the dynamic, multi-player, but nevertheless hierarchically structured politics of national memory within the United States itself. Next I analyzed how historical reasoning was used in academic training for government service and foreign policy decision making in the late Cold War. In the final section of this article, I analyzed the United States Information Agency as the Cold War apparatus for a memory policy in Transatlantic relations. As my case study of the US Constitution's bicentennial programming demonstrated, while such a memory 
policy may not have been articulated in any single central US government document, it can still be assembled from the blueprints for foreign policy training, and the public statements, diplomatic correspondence, and commemorative practices of the time. The United States Information Agency was capable of implementing such a Transatlantic memory policy during the Cold War and much of the 1990s. The question for researchers of the post-Communist era is to what extent USIA engaged in such memory diplomacy after the end of the Cold War - and who took on this function after the agency was dismantled in 1999.

\section{Acknowledgments}

This article was made possible through support of the Grant Agency of the Czech Republic, grant number 14-21581S - Role of collective memory in transatlantic relations after the end of the Cold War.

\section{Biographical Note}

Dr. György "George" Tóth is Lecturer in post-1945 U.S. History and Transatlantic Relations and Academic Director of the Atlantic Studies Masters program at the University of Stirling, Scotland, the United Kingdom. His research specializes in the use of culture in U.S. transnational and transatlantic relations in the Cold War and beyond. His forthcoming book titled From Wounded Knee to Checkpoint Charlie chronicles the transatlantic alliance between American Indian sovereignty activists and Central European groups in the late Cold War.

E-mail: gyorgy.toth@stir.ac.uk 